\title{
The Influence of School-Based Management and Teacher's Professionalism toward Teacher's Performance
}

\author{
Siti Rohma \\ SMP Negeri 2 Prabumulih, Indonesia \\ e-mail: sitirohmaguru@gmail.com \\ Edi Harapan \\ Universitas PGRI Palembang, Indonesia \\ e-mail: ehara205@gmail.com \\ Dessy Wardiah \\ Universitas PGRI Palembang, Indonesia \\ e-mail: dessywardiah77@ gmail.com
}

Article History: Received on 14 July 2020, Revised on 19 July 2020, Published on 27 July 2020

\begin{abstract}
This study determined the influence of school-based management and teacher's professionalism both partially and simultaneously on the performance of teachers of State Junior High Schools in Prabumulih Timur, Indonesia. The sample of this study were 135 civil servant teachers. Research data collection techniques 1) questionnaire; 2) documentation; and 3 ) observation. The research data analysis technique used the SPSS for Windows 21. The results of this study indicate that: 1) there is a significant influence of school-based management on the performance of state junior high school teachers in the District of Prabumulih Timur, Prabumulih City; 2) there is a significant influence of teacher's professionalism on the performance of teachers of SMP Negeri in the District of Prabumulih Timur, Prabumulih City; 3) there is a significant influence of school-based management and teacher's professionalism together on the performance of teachers of SMP Negeri in Prabumulih Timur, Indonesia.
\end{abstract}

Keywords: School-Based Management; Teacher's Professionalism; Teacher's Performance

\section{A. Introduction}

Schools as part of institutions that must be responsible for providing services to students and stakeholders must be able to provide excellent service both in terms of teaching administration, student affairs, staffing, finance and other educational facilities while continuing to prioritize effective and efficient services one of the ways that madrasas or schools do is to use school-based management, which is a management model that gives autonomy greater authority and responsibility to schools, flexibility, encourages direct participation of school and community members, improves school quality based on national policy. Some reasons for using this approach are 1) the importance of school autonomy, with this autonomy the school will be able to develop schools or madrasas optimally by looking at the potential they have while taking into account local wisdom. 2) flexible, with SBM schools or madrasas more freely and aggressively utilizing school resources, 3) with SBM schools will know the strengths, weaknesses, opportunities and threats that exist, 4) schools know what needs to be improved, thus schools or 
madrasas able to make programs based on needs and focus on solving existing problems, 5) the decision is determined by the school or madrasa, because the most know the condition of the school is the school or madrasah itself, 6) more efficient use of resources, 7) citizen involvement schools and communities, 8) schools are responsible for the quality of their respective education to the government, 9) schools can conduct healthy competition with other schools, 10) schools can immediately respond to community and environmental aspirations quickly (Rohiat, 2010).

Law Number 32 of 2004 concerning Regional Autonomy which states that, School Based Management (SBM) is a study that is widely discussed to change the education system in Indonesia from centralistic to decentralized since its enactment states that education is one of the fields of government that must be implemented by the regional government. Along with autonomy and the principle of decentralization, improving quality requires participation and empowerment of all components of education and the application of the concept of education as a system. Decentralization is expected to increase cooperation between principals, teachers, staff and the community in improving quality and productivity (Nurkholis, 2016: 24).

School Based Management will take place effectively and efficiently if supported by professional human resources to operate the school, sufficient funds so that schools are able to pay staff according to their functions, adequate infrastructure to support the teachinglearning process, and community support (parents of students) who are high both in terms of thought assistance and financial donations (Kurniadin, 2013). Burhanuddin (2015) explains that School Based Management is an educational management model that provides educational autonomy to schools and this model encourages decision-making to always involve all school members who are served while still aiming at the national education goals of Suparlan (2014) explains that School Based Management is a very popular educational policy. Officials often deliver on various occasions speeches in front of teachers and school principals. Even parents of students also know a lot from the school committee or get it from training opportunities.

Education is one of the most important and strategic aspects in the development and improvement of development in all fields, including in the regions, so that the decentralization of education in the context of regional autonomy cannot be negotiated in order to improve the quality of education and human resources. One model of education decentralization is School Based Management, which aims to improve the quality of education in Indonesia (Mulyasa, 2013).

School Based Management is one of the bureaucratic reform models as a consequence of decentralization in the world of education to create a form of future school that is better than the previous one. SBM emphasizes that the concept refers to resource management at the school level and not at a centralized system or level (Hasbullah, 2012: 65).

One of the most important features of implementing SBM is how schools are able to provide satisfying educational services to parents of students and the community and vice versa to what extent the readiness and role of the community and students' parents in contributing to developing and improving school quality is in accordance with community needs. Implementation of SBM in schools requires the readiness of various components and educational equipment both internally and externally that can support the implementation of SBM itself, among others: school buildings equipped with learning facilities and infrastructure, principals, educators and education personnel, students, students, the 
environment school participation of parents of students, community support and other business worlds (Supriadi, 2014: 135).

This effort is directed so that each educational institution always strives to provide quality assurance to the parties concerned, both the teachers themselves and students as learning communities, namely a quality guarantee that the delivery of education in the schools is in accordance with what is supposed to occur and is appropriate also with their hopes. If every educational provider always strives to provide quality assurance and this effort is carried out continuously, it is hoped that the quality of education nationally will continue to improve (Anwar, 2013: 12).

Based on the description above, the researcher can assume that the effort to improve teacher's professionalism certainly needs a number of things, including school-based management that must be improved and implemented according to the rules, teacher's professionalism must be improved by giving directives from school principals, supervisors so that the effort itself teacher's performance goals can be achieved as expected. Teachers must also be provided with provisions to deliver learning material to students, for example given training and education supplies, workshops, seminar workshops, so that teachers can find out about the development of the education world as needed. This was confirmed by Kurniasih (2017: 19) that the teacher is a profession whose position or occupation requires special expertise. The task of the teacher as a profession includes: educating, teaching and training. Educating means developing life values, teaching means continuing and developing science and technology, while training means developing students' skills.

The teacher is an educator whose main task is to teach, in the sense of developing the realm of creativity, taste and intention of students as the ideal concept of educating implementation. Teacher personality characteristics include: cognitive flexibility, and psychological openness. We hope that teachers will be able to compete and work professionally. Teacher competence is the ability and authority of teachers in carrying out their profession, while professionalism means the special qualities and behaviors that characterize professional teacher; teachers are also expected to be able to carry out an integral and reciprocal activity between teacher and students in instructional situations. In this situation the teacher teaches and students learn (Zahroh, 2015: 33).

Sani (2017: 4) states that in accordance with the Law of the Republic of Indonesia No. 20 of 2003, concerning the National Education System, the position of teacher as an educator is a professional position. For this reason, teacher's professionalism is demanded to continue to develop in accordance with the changing times, science and technology, and the needs of the community, including the need for quality human resources and capability to be able to compete in regional, national and international forums.

According to Mangkunegara (2011: 21) teacher's performance is a learning process as an effort to develop existing activities into better activities, so that educational goals that have been set are achieved well through a learning activity carried out by teachers in accordance with the targets and objectives. Furthermore Rusyan (2016: 47) states that teacher's performance is implementing the learning process both carried out in the classroom and outside the classroom in addition to working on other activities, such as working on school administration and learning administration, carrying out guidance and services to students, and implementing assessment. 
The main factor why humans work is that there are needs that must be met. Activities in work contain elements of a social activity that produces something and ultimately aims to meet needs and to achieve a better standard of living. In achieving a better standard of living and success in work cannot be separated from work motivation, and the strength or weakness of one's work motivation affects the level of performance (Kurniasih, 2017: 23).

In relation to the world of education, teacher's performance can be defined as the extent to which a teacher works to the fullest in accordance with his abilities in an effort to achieve institutional goals. The ability of a teacher will be seen when teaching that can be measured from the teaching competence (Kurniasih, 2017: 23). Zahroh (2015: 12) defines performance as a reflection of the overall way a person sets goals for his achievement. A good teacher works with careful planning so that the planned objectives can be achieved. Performance differences between one person and another in a work situation are due to differences in the characteristics of individuals.

Basically, Performance is influenced by two factors, namely individual factors and situation factors. On the individual factor, if someone sees a high performance is a path to meet their needs, then he will follow that path. While the situation factor states that performance is the result of interaction between motivation and basic abilities. If motivation is high but basic ability is low, then performance will be low and if ability is high but motivation is low then performance will be low, or vice versa (Nanang, 2016: 48).

Zahroh (2015: 13) suggests that teacher's performance appraisal is very important because it answers their fundamental questions about how good the quality of teaching is. Performance appraisal feedback will provide several things including: assurance that the teacher is contributing and doing the right things, awareness of the impact of teaching performance on desired outcomes (eg, student satisfaction), Performance measures (quality, quantity, speed, etc.), recognition of the importance and value of teacher's performance. Performance produces outcomes for the organization and rewards for personnel in the form of salaries, benefits, job guarantees, recognition from coworkers and superiors, and promotional opportunities for individual employees. This is in line with motivator factors and health factors.

Preliminary observations of researchers obtained information that in the District of East Prabumulih, there are 3 (three) State Junior High Schools, namely 5 Public Schools of Prabumulih, 8 Public Schools of Prabumulih and 12 Public Schools of 12 Prabumulih. Based on preliminary interviews with the Principal of Prabumulih 5 Public Middle School, Principal of 8 Prabumulih Public Middle School, and Principal of 12 Prabumulih Public Middle School, information was obtained that the School Based Management in each school was in accordance with the directions and instructions of the Prabumulih Education Office and was programmed To improve the quality of education, the benefits are not yet maximally felt, because the funds are very limited, while the educational needs in schools are numerous, so that it is carried out as efficiently as possible to be shared by mapping so that everything can be fulfilled even though it has not been maximized. Besides that, teacher's professionalism has not indicated the truth, in other words, teacher's professionalism has not shown the expected professionalism. This certainly affects the performance of the teacher itself. The school principal has tried and endeavored to improve teacher's professionalism and teacher's performance by sending teachers to attend training, attend seminars. So that the teacher's knowledge and understanding in teaching can be even better. The Principal also explained that there were still teachers who were 
undisciplined in carrying out their duties, such as arriving late, some were absent due to family affairs, there were also teachers who taught through lectures and assignments, sometimes without giving an explanation first. In other words, teacher's professionalism is not optimal, and teacher's performance needs to be improved.

Based on the description from the background above, the problems that exist in this study are 1) is there an influence of school-based management on the performance of teachers of state junior high schools in Prabumulih Timur District, Prabumulih City?; 2) is there an influence of teacher's professionalism on the performance of teachers of State Junior High Schools in Prabumulih Timur District, Prabumulih City?; and 3) is there an influence of school-based management and teacher's professionalism on the performance of teachers of State Junior High Schools in Prabumulih Timur District, Prabumulih City?

\section{B. Methods}

Sugiyono (2015: 312) argues that quantitative research methods can be interpreted as a research method based on the philosophy of positivism, used to examine populations and certain samples, sampling techniques are generally carried out randomly, data collection using research instruments, quantitative data analysis/statistics with the aim to test the hypothesis that has been set. Furthermore, according to Arikunto (2010: 327), the research method is a scientific way to obtain data that has special rational, empirical and systematic characteristics. The method in this research is a quantitative method with a survey approach. In line with this research, according to Sugiyono (2015: 314) suggested that the survey method is used to obtain data on a particular place that is natural (not artificial), but researchers conduct treatment in data collection for example by distributing questionnaires, tests, structured interviews and so on (treatment not as in experiments).

Arikunto (2010: 183) argues that in a study needed data. In collecting data, techniques are needed, both techniques in providing data, as well as techniques in classifying collected data. A similar sentiment was also stated by Sugiyono (2015:312) that the data collection method is a method used to collect data, while the data collection technique is the method adopted in carrying out the chosen method. In brief, it can be noted that the method is the way, while the technique is the way to run the method that has been selected.

Questionnaire can be called a written interview because the contents of the questionnaire are a series of questions or written statements addressed to the respondent and filled out by the respondent themselves (Arikunto, 2010: 195). In this study, researchers used data collection tools, questionnaire as the main instrument. Questionnaire presented varies with alternative answers: 1) Always (SL), 2) Often (SR), 3) Rarely (JR), 4) Never (TP) (Sugiyono, 2015: 199). Questionnaires were given to each of the 135 junior high school teachers in Prabumulih Timur, as the researchers described in the sample above relating to school-based management and teacher's professionalism on the performance of the teachers of the state junior high school in Prabumulih Timur.

Documentation is a data collection technique to obtain written facts in the form of documents, reports, archives and or other written materials related to the focus of research (Arikunto, 2010: 196). In connection with documentation techniques, researchers take data in the form of photographs when the study was conducted and the minutes that researchers prepared as supporting data, as well as archives of letters relating to research data, such as 
Volume 1 (1) 2020

E-ISSN: 2723-6919

questionnaire sheets that were prepared and questionnaires that were filled out by each teacher samples, research permits and so on.

According to Arikunto (2010: 74) observation is interpreted as systematic observation and recording of symptoms that appear on the research object. Observations and records made of symptoms that appear on the object at the place of occurrence or occurrence of events, so that the observer is with the object being investigated, called observations observations that researchers will carry out are direct observations of events such as how the school-based management process and teacher's professionalism or teacher's performance in the learning process in each school.

Based on the description above, the focus of this research study in the observation activities was carried out at SMP Negeri 5 Prabumulih, SMP Negeri 8 Prabumulih and at SMP Negeri 12 Prabumulih. Observation data that will be used as research support material and other supporting data to supplement research data, namely the process of implementing teaching of teachers in the classroom.

\section{Results and Discussion}

Before the questionnaire was distributed to each teacher used as a sample in this study, the questionnaire was first tested to teachers outside the sample in this study. In this case, the researcher took a sample of the trial is a PNS 2 Prabumulih PNS teacher in Prabumulih Timur with a total of 53 teachers. The results of the questionnaire test were stated to be all valid and reliable and had a significant value $>\alpha 5 \%$, so that they could be included in further research. As the researchers have pointed out, that in this study the Kolmogorov-smirnov test can be used, the criterion is significant for a two-sided test the results of calculations greater than> 0.05 means normal distribution.

According to Santoso (2010: 36) for the normality test the Kolmogorov-Smirnov test can be used from the Statistical Program for Social Science (SPSS) software program for Windows Version 21. The normality of data distribution is calculated by comparing the Asymptotic Significance score obtained with the score $\alpha=0.5$. If Asymp Sig. $>0.05$, then the data is declared normal (Prayitno, 2010: 40), as shown in the following table.

Table 1 . Normality Testing

\begin{tabular}{|c|c|c|c|c|}
\hline \multicolumn{5}{|c|}{ One-Sample Kolmogorov-Smirnov Test } \\
\hline & & $\begin{array}{l}\text { School Based } \\
\text { Management }\end{array}$ & $\begin{array}{c}\text { Teacher's } \\
\text { Professionalism }\end{array}$ & $\begin{array}{c}\text { Teacher's } \\
\text { Performance }\end{array}$ \\
\hline \multicolumn{2}{|l|}{$\mathrm{N}$} & 135 & 135 & 135 \\
\hline \multirow[b]{2}{*}{ Normal Parameters ${ }^{\mathrm{a}, \mathrm{b}}$} & Mean & 2.9436 & 3.3074 & 3.0015 \\
\hline & $\begin{array}{l}\text { Std. } \\
\text { Deviation }\end{array}$ & .27431 & .24128 & .20612 \\
\hline \multirow{3}{*}{$\begin{array}{l}\text { Most Extreme } \\
\text { Differences }\end{array}$} & Absolute & .066 & .074 & .085 \\
\hline & Positive & .066 & .057 & .085 \\
\hline & Negative & -.065 & -.074 & -.072 \\
\hline \multirow{2}{*}{\multicolumn{2}{|c|}{$\begin{array}{l}\text { Kolmogorov-SmirnovZ } \\
\text { Asymp. Sig. (2-tailed) }\end{array}$}} & .771 & .857 & .987 \\
\hline & & .591 & .455 & .284 \\
\hline
\end{tabular}
a. Test distribution is Normal.
b. Calculated from data. 
Volume 1 (1) 2020

E-ISSN: 2723-6919

Based on the description in the normality test table above, it shows that the results of the analysis obtained value on the $\mathrm{X}_{1}$ variable has a value of $0.591>0.05$, meaning that schoolbased management has an influence on teacher's performance and can be said to be normally distributed. In variable $\mathrm{X}_{2}$ has a value of $0.455>0.05$, meaning that teacher's professionalism has an influence on teacher's performance and can be said to be normally distributed. On the $\mathrm{Y}$ variable in other words the variables $\mathrm{X}_{1}$ and $\mathrm{X}_{2}$ (school-based management and teacher's professionalism) have an influence on teacher's performance by $0.230>0.05$. the meaning of the two variables, $\left(\mathrm{X}_{1}\right)$ and $\left(\mathrm{X}_{2}\right)$ give joint influence on teacher's performance and normal distribution.

Before using multiple linear regression analysis, the requirements that must be met are to test its homogeneity. Homogeneity testing is needed to determine whether the data are from the same population or are called homogeneous. Homogeneity testing in this study was performed using the Chi-Square test by setting the significance of 5\% $(a=0.06)$, the homogeneity interpretation of the data was calculated based on the Asymtotic Significance value obtained. If Asymp.Sig. > 0.06, then the data is declared homogeneous (Prayitno, 2010: $108)$, as can be seen in the following table.

Table 2. Homogeneity testing

Test Statistics

\begin{tabular}{|l|r|r|r|}
\hline & $\begin{array}{c}\text { School Based } \\
\text { Management }\end{array}$ & $\begin{array}{c}\text { Teacher's } \\
\text { Professionalism }\end{array}$ & $\begin{array}{c}\text { Teacher's } \\
\text { Performance }\end{array}$ \\
\hline Chi-Square & $45.556^{\mathrm{a}}$ & $29.333^{\mathrm{b}}$ & $51.778^{\mathrm{c}}$ \\
\hline Df & 24 & 20 & 22 \\
Asymp. Sig. & .206 & .359 & .170 \\
\hline
\end{tabular}

Based on the description in the homogeneity test table above, it shows that school-based management has an influence on the performance of teachers of state junior high schools in Prabumulih Timur. It is known from the results of the analysis obtained a value of sig. 0,206> 0.06 . Thus, it can be said that the independent variable $\left(\mathrm{X}_{1}\right)$ gives a positive influence on the variable $\mathrm{y}$ and is declared homogeneous. Furthermore, the influence of teacher's professionalism on the performance of teachers of SMP Negeri in the District of Prabumulih Timur had a positive influence with the value obtained of $0.359>0.06$. Thus, it can be said that the independent variable $\left(\mathrm{X}_{2}\right)$ gives a positive influence on the variable $\mathrm{y}$ and is declared homogeneous. The influence of school-based management and teacher's professionalism on the performance of state junior high school teachers in Prabumulih Timur showed the results obtained by $0.170>0.06$. Thus, it can be said that the independent variables $\left(\mathrm{X}_{1}\right)$ and $\left(\mathrm{X}_{2}\right)$ together have a positive influence on the dependent variable (y) and can be said to be homogeneous.

Linearity test analysis of the effect of school-based management and teacher's professionalism on the performance of teachers of state junior high schools in Prabumulih Timur the researchers describe in the table below. 
Table 3. Linearity Testing $\mathrm{X}_{1}$ to $\mathrm{Y}$

\begin{tabular}{|c|c|c|c|c|c|c|c|}
\hline \multicolumn{8}{|c|}{ ANOVA Table } \\
\hline & & & $\begin{array}{l}\text { Sum of } \\
\text { Squares }\end{array}$ & $\mathrm{df}$ & $\begin{array}{l}\text { Mean } \\
\text { Square }\end{array}$ & $\mathrm{F}$ & Sig. \\
\hline \multirow{5}{*}{$\begin{array}{l}\text { Teacher's } \\
\text { Performance * } \\
\text { School Based } \\
\text { Management }\end{array}$} & & (Combined) & 1.691 & 24 & .070 & 1.937 & .011 \\
\hline & Between & Linearity & .365 & 1 & .365 & 10.020 & .002 \\
\hline & Groups & $\begin{array}{l}\text { Deviation } \\
\text { from Linearity }\end{array}$ & 1.327 & 23 & .058 & 1.585 & .060 \\
\hline & \multicolumn{2}{|c|}{ Within Groups } & 4.002 & 110 & .036 & & \\
\hline & \multicolumn{2}{|c|}{ Total } & 5.693 & 134 & & & \\
\hline
\end{tabular}

Based on the description in the table above, it shows that $F_{\text {count }}>F_{\text {table }}$ is the value in the dev level. From linearity of $0.60>0.06$. Thus it can be said that school-based management is linear to teacher's performance.

Table 4. Linearity Testing $\mathrm{X}_{2}$ to $\mathrm{Y}$

\begin{tabular}{|c|c|c|c|c|c|c|c|}
\hline \multicolumn{8}{|c|}{ ANOVA Table } \\
\hline & & & $\begin{array}{l}\text { Sum of } \\
\text { Squares }\end{array}$ & $\mathrm{df}$ & $\begin{array}{l}\text { Mean } \\
\text { Square }\end{array}$ & $\mathrm{F}$ & Sig. \\
\hline \multirow{5}{*}{$\begin{array}{l}\text { Teacher's } \\
\text { Performance* } \\
\text { Teacher's } \\
\text { Professionalisn }\end{array}$} & & (Combined) & 1.172 & 20 & .059 & 1.477 & .103 \\
\hline & Between & Linearity & .306 & 1 & .306 & 7.715 & .006 \\
\hline & Groups & $\begin{array}{l}\text { Deviation } \\
\text { from Linearity }\end{array}$ & .866 & 19 & .046 & 1.149 & .314 \\
\hline & \multicolumn{2}{|c|}{ Within Groups } & 4.521 & 114 & .040 & & \\
\hline & \multicolumn{2}{|l|}{ Total } & 5.693 & 134 & & & \\
\hline
\end{tabular}

Based on the description in the table above, it shows that $\mathrm{F}_{\text {count }}>\mathrm{F}_{\text {table }}$ is the value in the line dev. From linearity of $0.314>0.06$. Thus it can be said that teacher's professionalism is linear to teacher's performance.

Hypothesis testing is used to calculate the frequency distribution test at the significance level of $5 \%$. Ho is rejected if the value of $F_{\text {count }}>F_{\text {table }}$ or significance $\rho$ is smaller than $\alpha$. The results obtained can be seen in the following table.

Table 5. Hypothesis Testing $\mathrm{X}_{1}$ to $\mathrm{Y}$

\begin{tabular}{|l|r|r|r|r|r|}
\hline \multicolumn{7}{|c|}{ Coefficients } \\
\hline Model & \multicolumn{2}{|c|}{$\begin{array}{c}\text { Unstandardized } \\
\text { Coefficients }\end{array}$} & $\begin{array}{l}\text { Standardized } \\
\text { Coefficients }\end{array}$ & $\mathrm{t}$ & Sig. \\
\cline { 2 - 6 } & \multicolumn{1}{c|}{$\mathrm{B}$} & $\begin{array}{c}\text { Std. } \\
\text { Error }\end{array}$ & Beta & & \\
\hline (Constant) & 2.442 & .186 & & 13.103 & .000 \\
\hline School Based Management & .190 & .063 & .253 & 3.017 & .003 \\
\hline
\end{tabular}

a. Dependent Variable: Teacher's Performance 
Volume 1 (1) 2020

E-ISSN: 2723-6919

Based on the table above, the results obtained by the influence of school-based management on the performance of teachers of State Junior High Schools in Prabumulih Timur were $0.253>0.05$. This means that $\mathrm{F}_{\text {count }} 0.253>0.05 \mathrm{~F}_{\text {table }}$ with a significance level of $5 \%$. Thus it can be stated that the hypothesis proposed in this study is that there is an influence of management on the State Junior High School in the District of Prabumulih Timur, can be verified. Furthermore, researchers describe the hypothesis test $\mathrm{X} 2$ against $\mathrm{Y}$ as can be seen in the following table.

Table 5. Hypothesis Testing $\mathrm{X}_{2}$ to $\mathrm{Y}$

\begin{tabular}{|c|c|c|c|c|c|}
\hline \multicolumn{6}{|c|}{ Coefficients } \\
\hline \multirow[t]{2}{*}{ Model } & \multicolumn{2}{|c|}{$\begin{array}{l}\text { Unstandardized } \\
\text { Coefficients }\end{array}$} & $\begin{array}{l}\text { Standardized } \\
\text { Coefficients }\end{array}$ & $\mathrm{t}$ & Sig. \\
\hline & $\mathrm{B}$ & Std. Error & Beta & & \\
\hline (Constant) & 2.346 & .239 & & 9.820 & .000 \\
\hline Teacher's Professionalism & .198 & .072 & .232 & 2.749 & .007 \\
\hline
\end{tabular}

a. Dependent Variable: Teacher's Performance

Based on the table above, the results obtained by the influence of teacher's professionalism on the performance of teachers of State Junior High Schools in Prabumulih Timur were $0.232>0.05$. This means that $F_{\text {count }}$ is $0.232>F_{\text {table }} 0.05$ with a significance level of $5 \%$. Thus it can be stated that the hypothesis proposed in this study is that there is an influence of the professionalism of the teachers of State Junior High Schools in Prabumulih Timur can be verified. Furthermore, researchers describe the influence of $X_{1}$ and $X_{2}$ together against $Y$, as can be seen in the following table.

Table 6. Hypothesis Testing $\mathrm{X}_{1}$ and $\mathrm{X}_{2}$ to $\mathrm{Y}$

\begin{tabular}{|l|r|r|r|r|r|}
\hline \multicolumn{1}{|c|}{ Coefficients } & Sig. \\
& \multicolumn{2}{|c|}{$\begin{array}{c}\text { Unstandardized } \\
\text { Coefficients }\end{array}$} & $\begin{array}{c}\text { Standardized } \\
\text { Coefficients }\end{array}$ & t & \\
\cline { 2 - 5 } & \multicolumn{1}{|c|}{ B } & $\begin{array}{c}\text { Std. } \\
\text { Error }\end{array}$ & Beta & & \\
\hline (Constant) & 1.903 & .282 & & 6.753 & .000 \\
School Based Management & .174 & .062 & .253 & 2.796 & .006 \\
Teacher's Professionalism & .177 & .071 & .232 & 2.510 & .013 \\
\hline
\end{tabular}

a. Dependent Variable: Teacher's Performance

Based on the above table, it turns out the results obtained by the influence of school-based management and teacher's professionalism together on the performance of teachers of State Junior High Schools in the District of Prabumulih Timur amounted to 0.253>0.05. This means that $\mathrm{F}_{\text {count }}$ is $0.253>\mathrm{F}_{\text {table }} 0.05$ with a significance level of $5 \%$ and a value of $0.232>$ 0.05 . This means that $F_{\text {count }}$ is $0.232>F_{\text {table }} 0.05$ with a significance level of 5\%. Thus it can be stated that the hypothesis proposed in this study is that there is an influence of schoolbased management and teacher's professionalism together on the performance of teachers of Public Middle Schools in the District of Prabumulih Timur can be verified. 


\section{Conclusion}

Based on the results of the study it can be concluded that 1) there is a significant influence between school-based management on the teacher's performance of SMP Negeri in Prabumulih Timur; 2) there is a significant influence between teacher's professionalism on the teacher's performance of SMP Negeri in Prabumulih Timur; 3) there is a significant influence between school-based management and teacher's professionalism both simultaneously and partially on the teacher's performance of SMP Negeri in Prabumulih Timur.

\section{E. Acknowledgement}

We would like to express our special thanks and gratitude to Principal of SMP Negeri 2 Prabumulih and Rector Universitas PGRI Palembang who gave us the support to do this wonderful project. This project was funded independent. Secondly, we would also like to thank our friends who helped us a lot in finalizing this project within the limited time frame.

\section{REFERENCE}

Anwar, M. (2013). Administrasi Pendidikan dan Manajemen Biaya Pendidikan [Educational administration and management costs of education]. Jakarta: Raja Grafindo Persada.

Arikunto, S. (2010). Prosedur Penelitian Suatu Pendekatan Praktek [Research Procedure A Practical Approach]. Jakarta: Rineka Cipta.

Burhanuddin. (2015). Analisis Administrasi, Manajemen dan Kepemimpinan Pendidikan [Analysis of Administration, Management and Educational Leadership]. Jakarta: Bumi Aksara.

Hasbullah. (2012). Otonomi Pendidikan, Kebijakan Otonomi Daerah dan Implikasinya terhadap Penyelenggaraan Pendidikan [Educational Autonomy, Regional Autonomy Policy and Its Implications for Providing Education]. Jakarta: Raja Grafindo Persada.

Kurniadin, D., \& Machali, I. (2013). Manajemen Pendidikan Konsep dan Prinsip Pengelolaan Pendidikan [Educational Management Concepts and Principles for Educational Management]. Yogyakarta: Ar-Ruzz Media.

Kurniasih, I. (2017). Kompetensi Pedagogik, Teori dan Praktik Untuk Peningkatan Kinerja dan Kualitas Guru [Pedagogical Competence, Theory and Practice for Improving Teacher's performance and Quality]. Jakarta: Kata Pena.

Law Number 32 of 2004

Law of the Republic of Indonesia No. 20 of 2003

Mangkunegara. (2011). Kinerja Guru dan Upaya Meningkatkannya [Teacher's performance and Efforts to Improve It]. Jakarta: www.emaskuwinggo-mangkunegara.html. 
Journal of Social Work and Science Education

Volume 1 (1) 2020

E-ISSN: 2723-6919

Mulyasa, E. (2013). Manajemen Berbasis Sekolah, Konsep Strategi dan Implementasi [School Based Management, Strategy Concepts and Implementation]. Bandung: Remaja Rosdakarya.

Nanang. (2016). Strategi Pendidikan [Educational Strategy]. Jakarta: Raja Graffindo Persada.

Nurkholis. (2016). Manajemen Berbasis Sekolah, Teori Model dan Aplikasi [School Based Management, Model Theories and Applications]. Jakarta: Gramedia Widiasarana Indonesia

Rohiat. (2010). Manajemen Sekolah: Teori Dasar dan Praktik [School Management: Basic Theory and Practice]. Bandung: Refika Aditama.

Sugiyono. (2015). Metode Penelitian Pendidikan, Pendekatan Kuantitatif, Kualitatif dan $R$ \& D [Educational Research Methods, Quantitative Approaches, Qualitative and R\&D]. Bandung: Alfabeta.

Rusyan. (2016). Manajemen Peningkatan Kinerja Guru, Konsep Strategi dan Implementasi [Teacher's performance Improvement Management, Strategy Concepts and Implementation]. Bandung: Remaja Rosdakarya.

Sani, B. (2017). Kompetensi Pedagogik, Teori dan Praktik Untuk Peningkatan Kinerja dan Kualitas Guru [Pedagogical Competence, Theory and Practice for Improving Teacher's performance and Quality]. Jakarta: Kata Pena.

Supriadi. D. (2014). Membangun Bangsa Melalui Pendidikan [Building the Nation through Education]. Bandung: Remaja Rosdakarya.

Suparlan. (2014). Manajemen Berbasis Sekolah [School Based Management]. Jakarta: Rineka Cipta.

Zahroh, A. (2015). Membangun Kualitas Pembelajaran Melalui Dimensi Profesionalisme Guru [Building Quality Learning Through the Dimensions of Teacher's professionalism]. Bandung: Yrama Widya. 